VERSITA

VERSIT^

Research article
Acta Veterinaria-Beograd 2014, 64 (1), 138-148

UDK: $636.5 .087 .7 ; 665.528 .292 .94$

DOI: $10.2478 /$ acve-2014-0014

\title{
EVALUATION OF THE EFFECTS OF SALVIA OFFICINALIS \\ ESSENTIAL OIL ON PLASMA BIOCHEMISTRY, GUT MUCUS AND QUANTITY OF ACIDIC AND NEUTRAL MUCINS IN THE CHICKEN GUT
}

\author{
ČAPKOVIČOVÁ Adriana ${ }^{1}$, MAKOVÁ Zuzana ${ }^{1}$, PIEŠOVÁ Elena ${ }^{1}$, ALVES \\ Anabela ${ }^{3}$, FAIX Štefan ${ }^{2}$, FAIXOVÁ Zita ${ }^{1 *}$ \\ ${ }^{1}$ University of Veterinary Medicine and Pharmacy in Košice, Slovak Republic; ${ }^{2}$ Institute of Animal \\ Physiology, Slovak Academy of Sciences in Košice, Slovak Republic; ${ }^{3}$ Department of Veterinary Sciences, \\ CECAV, University of Tras-os-Montes and Alto Douro (UTAD), Vila Real, Portugal
}

(Received 12 January 2014; Accepted 24 January 2014)

\begin{abstract}
In this study the effects of Salvia officinalis L. essential oil on the thickness of the gut mucus layer and quantity of neutral and acidic mucins in chickens were observed. Oneday-old chickens of Isa Brown breed were divided into five groups $(\mathrm{n}=9)$ and fed 11 weeks as follows: control group (C): basal diet; experimental groups (E1 - E4) - same as $\mathrm{C}+$ sage essential oil (EO) in concentrations of $0.01 \% ; 0.025 \% ; 0.05 \%$ and $0.1 \%$, respectively. The thickness of the mucus layer in the duodenum significantly increased in $\mathrm{E} 3(0.05 \%$ sage EO) compared to E1 (0.01\% sage EO). In E3 (0.05\% sage EO) the number of goblet cells containing acidic and neutral mucins was significantly decreased in the duodenum and jejunum and increased in the ileum compared to C. Feeding the diet supplemented with Se and $0.01 \%$ sage EO (E1) decreased plasma cholesterol level in comparison with E3(0.05\% sage EO). The addition of $0.05 \%$ (E3) and $0.1 \%$ sage EO (E4) to the diet caused a decrease in calcium plasma level compared to E2 $(0.025$ $\%$ sage EO). Plasma glucose level was significantly decreased in groups fed $0.05 \%$ (E3) and $0.025 \%$ sage EO (E2) compared with $0.01 \%$ sage (E1). The weight of internal organs was not affected by the diets. Our results suggest that effects of sage EO on the adherent mucus layer dynamics and mucin type distribution in the chicken intestine are dependent on sage EO dose and intestinal segment and there is still a need for further studies in order to obtain a plausible explanation.
\end{abstract}

Key words: intestine, mucus, mucin, poultry, sage

\section{INTRODUCTION}

The epithelium of the intestinal tract is covered by a layer of mucus composed predominantly of mucin glycoproteins that are synthesized and secreted by goblet cells [1]. The mucus layer acts as a medium for protection, lubrication, transport, a physical barrier and a trap for microbes [2]. Histologically mucins can be separated into two broad categories: neutral and acidic. Mucin subtype and goblet cell distribution vary throughout the gastrointestinal tract.

\footnotetext{
*Corresponding author: e-mail: zita.faixova@uvlf.sk
} 
The thickness of the mucus adherent layer is affected by the rate of mucin secretion and by the rate of mucin degradation. Mucin secretion occurs via both constitutive and regulated pathways. The constitutive pathway continuously secretes sufficient mucin to maintain the mucus layer, whereas the regulated pathway results in a massive discharge as a response to various stimuli, including cholinergic stimuli, inflammatory cytokines, prostaglandins, lipopolysaccharides, bile salts, nucleotides, nitric oxide, vasoactive intestinal peptide, neutrophil elastase [3] and diet [1].

Degradation of mucin occurs by the mechanical shear forces of peristalsis and by degradating enzymes. The mucosal barrier is constantly renewed and can potentially be rapidly adjusted to changes in the (patho) physiological stimuli.

The use of antibiotics as growth promotors in animal feedstuffs is facing a reduced social acceptance and therefore the research for alternative feed supplements has been increased. Attention has been turned to essential oils of herbs and spices. There is evidence that essential oils have modulatory effects on the animal digestive system [4, 5]. Sage plants belong to the Lamiaceae family, and their EOs are known as inhibitors of inflammation, suppressors of blood glucose levels and strong antioxidants [6].

The aim of this study was to investigate the effect of dietary sage supplementation on gut mucus dynamics, blood biochemical indices and performance of chickens.

\section{MATERIALS AND METHODS}

\section{Animals and experimental groups}

Fourty-five one-day-old female chickens of the laying strain Isa Brown (Párovské Háje, Slovakia hatchery) were used. They were divided into five groups $(n=9)$ and fed as follows: control group $(\mathrm{C})$ : basal diet $(\mathrm{BD})+$ sodium selenite $(\mathrm{Se})(0.4 \mathrm{ppm})+$ sunflower oil (SO) (1\%); experimental groups (E1 - E4) - same as C + sage essential oil (EO) in concentrations of $0.01 \% ; 0.025 \% ; 0.05 \%$ and $0.1 \%$, respectively, for 11 weeks. The sage $\mathrm{EO}$ was dissolved in $\mathrm{SO}$ and then gently added to $\mathrm{BD}$ to reach the concentrations mentioned above. The birds were kept in group wooden cages with wooden shavings. The temperature and lightning regimen were in accordance with the recommendation of the breeder. All groups received the feed and water ad libitum. The composition of the basal diet supplemented with selenium as sodium selenite is shown in Table 1. The composition of the EO from the leaves of Salvia officinalis L., reported by the producer Calendula a.s., Nová Lubovňa, Slovakia, was as follows: camphor $14.9 \%, \alpha$-thujone $14.8 \%$, eucalyptol $8.5 \%$, $\beta$-thujone $7.2 \%$, borneol $3.7 \%$.

At the end of the experiment the chickens were anaesthetised by an intraperitoneal injection of xylazine (Rometar $2 \%$, Spofa, Czech Republic) and ketamine (Narkamon $5 \%$, Spofa, Czech Republic) at 0.6 and $0.7 \mathrm{ml} . \mathrm{kg}-1$ of body weight, respectively. The blood for biochemical measurements was collected into heparinized test-tubes and parameters (phosphorus, calcium, magnesium, AST, cholesterol, triglycerides and glucose) were determined by the colorimetric method using spectrophotometric kits (Randox lab, Ardmore, UK) and measured with Genesys 10 UV spectrophotometer. After laparotomy, internal body organs (liver without gall bladder, spleen, pancreas and empty gizzard without cuticula) were weighed and intestinal sections were collected. 
Table 1. Composition of the basal diet - nutritional analysis per $1 \mathrm{~kg}$

\begin{tabular}{|c|c|c|c|}
\hline Ingredient & Amount & Ingredient & Amount \\
\hline $\mathrm{N} \times 6.25$ & $\min .190 \mathrm{~g}$ & Co & $0.4 \mathrm{mg}$ \\
\hline Crude ME & $\min .12 \mathrm{MJ} / \mathrm{kg}$ & Se & $0.1+0.4 \mathrm{mg}$ \\
\hline Ash & $\max .50 \mathrm{~g}$ & Vitamin A & $\min .12000 \mathrm{IU}$ \\
\hline Fiber & $\max .35 \mathrm{~g}$ & Vitamin D3 & $\min .4000 \mathrm{IU}$ \\
\hline Lysine & $\min .905 \mathrm{~g}$ & Vit. E ( $\alpha$-tocopherol) & $\min .100 \mathrm{IU}$ \\
\hline Methionine & $\min .4 \mathrm{~g}$ & Vitamin K3 & $4 \mathrm{mg}$ \\
\hline Cystine & $\min .3 .5 \mathrm{~g}$ & Vitamin B1 & $3 \mathrm{mg}$ \\
\hline Linoleic acid & $\min .10 \mathrm{~g}$ & Vitamin B2 & $\min .9 \mathrm{mg}$ \\
\hline $\mathrm{Ca}$ & $\min .7 \mathrm{~g}$ & Vitamin B6 & $6 \mathrm{mg}$ \\
\hline $\mathrm{P}$ & $\min .5 \mathrm{~g}$ & Vitamin B12 & $\min .40 \mu g$ \\
\hline $\mathrm{Na}$ & $1.5 \mathrm{~g}$ & Vitamin C & $200 \mathrm{mg}$ \\
\hline Mn & $\min .110 \mathrm{mg}$ & Nicotinic acid & $60 \mathrm{mg}$ \\
\hline $\mathrm{Fe}$ & $\min .120 \mathrm{mg}$ & Calcium pantothenate & $15 \mathrm{mg}$ \\
\hline $\mathrm{Cu}$ & $\min .15 \mathrm{mg}$ & Folic acid & $2 \mathrm{mg}$ \\
\hline $\mathrm{Zn}$ & $\min .100 \mathrm{mg}$ & Biotine & $0.2 \mathrm{mg}$ \\
\hline I & $1 \mathrm{mg}$ & Choline & $500 \mathrm{mg}$ \\
\hline
\end{tabular}

\section{Determination of gut mucus adherent layer}

The gut samples (duodenum, jejunum, ileum and caecum) were processed for mucus determination using a method by Smirnov et al. [1], modified by Thompson and Applegate [7] and Faixová et al. [8]. The optical density of samples and standards was measured by ELISA reader (Opsys MR $^{\mathrm{TM}}$ Microplate Reader, Dynex Technologies INC., USA) at $630 \mathrm{~nm}$ wavelength. The amount of the adherent gut mucus stained by alcian blue (AB) (AppliChem GmbH, Germany) was calculated by a standard curve and expressed as $\mu \mathrm{g} \mathrm{AB.cm}{ }^{-2}$ of gut.

\section{Determination of mucins}

One - cm long middle segments of the duodenum, jejunum, ileum and caecum were removed, gently flushed with $0.9 \%$ (wt/vol) $\mathrm{NaCl}$ and fixed in $10 \%$ (vol/vol) formaldehyde for further processing. Segments were dehydrated, cleared, embedded in paraffin and cut into $3 \mu \mathrm{m}$ serial cross sections. Sections were deparaffinized in xylene and rehydrated in a graded alcohol series. Finally, they were stained with periodic acidSchiff (PAS) (Acros Organics, New Jersey, USA; Merck KGaA, Darmstadt, Germany), alcian blue (AB) (AppliChem GmbH, Germany) and combined AB/PAS staining [9]. Three sections for each staining were prepared to examine each individual intestinal segment.

\section{Image analysis}

For the PAS-, AB- and AB/PAS-stained sections, the color images were taken with a light microscope Nikon ECLIPSE E600 with Nikon digital camera DXM1200 and transferred to a TV monitor. From each section and each staining, 10 photos were taken and analyzed with Adobe Photoshop CS2 9.0. The surface area recorded on each photo was $0.09045 \mathrm{~mm}^{2}$. The goblet cells in the villi were counted on the mentioned area 
within each section and each staining. The number of goblet cells stained AB and PAS was converted to the area of $1 \mathrm{~mm}^{2}$.

\section{Statistical analysis}

The results are expressed as means \pm S.E.M. The statistical analysis was done by a one-way analysis of variance (ANOVA) with Tukey post-hoc multiple comparison test (GraphPad Software, USA).

The experiments were carried out in accordance with the established standards for the use of experimental animals. The protocol was approved by the local ethics and scientific authorities.

\section{RESULTS}

\section{Measurement of the mucus adherent layer thickness}

Feeding diet supplemented with Se and $0.05 \%$ sage EO (E3) significantly increased the thickness of the mucus layer in the duodenum compared with the group fed Se and $0.01 \%$ sage EO diet (E1) (Table 2).

Table 2. Effect of feeding the diet supplemented with selenium and Salvia officinalis L. essential oil on the thickness of gut mucus layer of chickens ( $\mu \mathrm{g}$ AB.cm-2 of gut)

\begin{tabular}{|c|c|c|c|c|c|}
\hline $\begin{array}{l}\text { Segment } \\
\text { of gut }\end{array}$ & $\begin{array}{c}\text { C } \\
0.4 \text { ppm } \\
\text { Se+ SO }\end{array}$ & $\begin{array}{c}\mathrm{E} 1 \\
0.4 \mathrm{ppm} \mathrm{Se}+ \\
\text { SO+ } 0.01 \% \\
\text { sage }\end{array}$ & $\begin{array}{c}\text { E } 2 \\
0.4 \mathrm{ppm} \mathrm{Se}+ \\
\text { SO }+0.025 \% \\
\text { sage }\end{array}$ & $\begin{array}{c}\mathrm{E} 3 \\
0.4 \mathrm{ppm} \mathrm{Se}+ \\
\mathrm{SO}+0.05 \% \\
\text { sage }\end{array}$ & $\begin{array}{c}\mathrm{E} 4 \\
0.4 \mathrm{ppm} \mathrm{Se}+ \\
\text { SO+0.1\% } \\
\text { sage }\end{array}$ \\
\hline Duodenum & $5.93 \pm 0.22$ & 4. $81 \pm 0.22^{\mathrm{a}}$ & $6.39 \pm 0.34$ & $7.27 \pm 0.44^{\mathrm{a}}$ & $6.13 \pm 0.37$ \\
\hline Jejunum & $5.15 \pm 0.21$ & $5.1 \pm 0.25$ & $6.47 \pm 0.46$ & $5.96 \pm 0.33$ & $6.37 \pm 0.45$ \\
\hline Ileum & $5.33 \pm 0.31$ & $4.84 \pm 0.21$ & $6.29 \pm 0.29$ & $6.09 \pm 0.34$ & $6.28 \pm 0.4$ \\
\hline Caecum & $5.48 \pm 0.33$ & $4.83 \pm 0.29$ & $5.23 \pm 0.24$ & $5.32 \pm 0.33$ & $6.22 \pm 0.35$ \\
\hline
\end{tabular}

Significant differences within a row are indicated by the same superscript (a) at $\mathrm{P}<0.05$ level; mean \pm S.E.M., $\mathrm{n}=9 ; \mathrm{AB}=$ alcian blue; $\mathrm{SO}=$ sunflower oil

\section{Quantification of cells containing acidic and neutral mucins}

In E3 (0.05\% sage EO) the duodenal and jejunal goblet cells exhibited a marked decrease in the number of cells containing both acidic and neutral mucins (Figure 1), while in the ileal goblet cells the increase of both types of mucins was observed when compared to the control group $(\mathrm{P}<0.05)$. The increase of number of cells containing acidic mucins in the duodenum and ileum was observed in E1 (0.01\% sage EO) and E2 $(0.025 \%$ sage EO), respectively $(\mathrm{P}<0.05)$ when compared to the control. On the other hand, the number of cells containing acidic mucins in the ileum of E4 $(0.1 \%$ sage $\mathrm{EO})$ and neutral mucins in the duodenum and jejunum of E4 (0.1\% sage EO) and E2 ( $0.025 \%$ sage EO), respectively, significantly decreased compared to control $(\mathrm{P}<0.05)$. The number of goblet cells containing acidic and neutral mucins in the caecum did not differ significantly between groups (Table 3). 


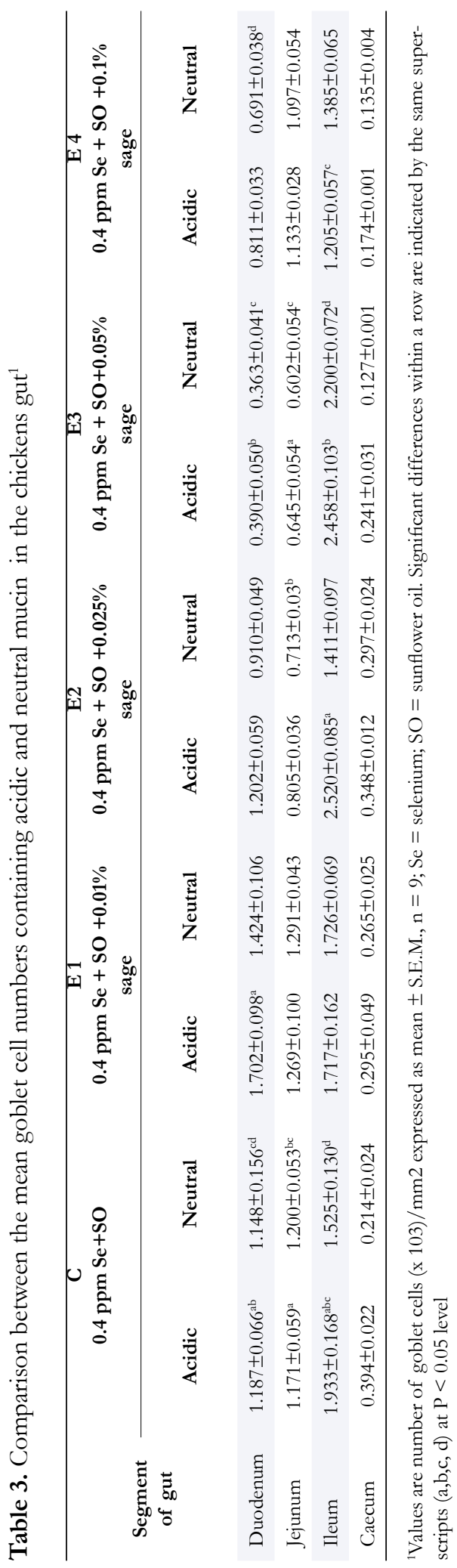




\section{Blood analysis}

The addition of sage extract $(0.05$ and $0.1 \%)$ to the Se -supplemented diet led to a decreased level of plasma calcium compared to E2 (0.025\% sage EO) (Table 4) (Ca reference values: $\left.2.09-2.52 \mathrm{mmol}^{-1} \mathrm{l}^{-1}\right)$ [10]. Feeding diet supplemented with $0.01 \%$ sage $\mathrm{EO}$ and Se caused a significant decrease in plasma cholesterol level compared to E3 $\left(0.05 \%\right.$ sage EO) (cholesterol reference values: 1.90 - 2.40 mmol. $\left.^{-1}\right)$ [10].

Table 4. Effect of feeding the diet supplemented with selenium and Salvia officinalis L. essential oil on biochemical parameters in the plasma of chicks.

\begin{tabular}{|c|c|c|c|c|c|}
\hline & $\begin{array}{c}\mathrm{C} \\
0.4 \mathrm{ppm} \mathrm{Se}+ \\
\text { SO }\end{array}$ & $\begin{array}{c}\text { E1 } \\
0.4 \mathrm{ppm} \mathrm{Se}+ \\
\text { SO+ } 0.01 \% \\
\text { sage } \\
\end{array}$ & $\begin{array}{c}\mathrm{E} 2 \\
0.4 \mathrm{ppm} \mathrm{Se}+ \\
\mathrm{SO}+0.025 \% \\
\text { sage } \\
\end{array}$ & $\begin{array}{c}\text { E3 } \\
0.4 \mathrm{ppm} \mathrm{Se}+ \\
\text { SO+ } 0.05 \% \\
\text { sage } \\
\end{array}$ & $\begin{array}{c}\mathrm{E} 4 \\
0.4 \mathrm{ppm} \mathrm{Se}+ \\
\text { SO+ } 0.1 \% \\
\text { sage } \\
\end{array}$ \\
\hline $\begin{array}{l}\text { Glucose } \\
\left(\text { mmol. }^{-1}\right)\end{array}$ & $19.85 \pm 1.51$ & $24.13 \pm 2.28^{\mathrm{ab}}$ & $15.53 \pm 1.45^{\mathrm{b}}$ & $16.9 \pm 1.1^{\mathrm{a}}$ & $18.6 \pm 0.9$ \\
\hline $\mathrm{Ca}\left(\mathrm{mmol.} \mathrm{l}^{-1}\right)$ & $2.47 \pm 0.16^{\mathrm{cd}}$ & $1.82 \pm 0.07$ & $2.19 \pm 0.13^{\mathrm{ab}}$ & $1.39 \pm 0.03^{\mathrm{bc}}$ & $1.5 \pm 0.1^{\mathrm{ad}}$ \\
\hline $\mathrm{P}\left(\mathrm{mmol} . \mathrm{l}^{-1}\right)$ & $2.01 \pm 0.01$ & $1.98 \pm 0.21$ & $2.1 \pm 0.07$ & $2.08 \pm 0.15$ & $2.60 \pm 0.11$ \\
\hline AST $\left(\mu k a t . l^{-1}\right)$ & $0.96 \pm 0.03$ & $1.04 \pm 0.05$ & $0.94 \pm 0.05$ & $0.93 \pm 0.02$ & $0.9 \pm 0.03$ \\
\hline $\operatorname{Mg}\left(\mathrm{mmol} . \mathrm{l}^{-1}\right)$ & $0.68 \pm 0.05$ & $0.73 \pm 0.04$ & $0.85 \pm 0.05$ & $0.69 \pm 0.07$ & $0.84 \pm 0.04$ \\
\hline $\begin{array}{l}\text { Triglycerides } \\
\left({\left.\text { mmol. } 1^{-1}\right)}^{-1}\right.\end{array}$ & $0.28 \pm 0.05$ & $0.23 \pm 0.03$ & $0.20 \pm 0.02$ & $0.38 \pm 0.06$ & $0.35 \pm 0.05$ \\
\hline $\begin{array}{l}\text { Cholesterol } \\
\left(\mathrm{mmol}^{-1} \mathrm{I}^{-}\right)\end{array}$ & $1.78 \pm 0.12$ & $1.23 \pm 0.08^{\mathrm{a}}$ & $1.52 \pm 0.12$ & $2.28 \pm 0.3^{\mathrm{a}}$ & $1.98 \pm 0.15$ \\
\hline
\end{tabular}

Significant differences within a row are indicated by the same superscripts (a,b,c,d) at $\mathrm{P}<0.01$ level; mean \pm S.E.M., $\mathrm{n}=9 ; \mathrm{SO}=$ sunflower oil

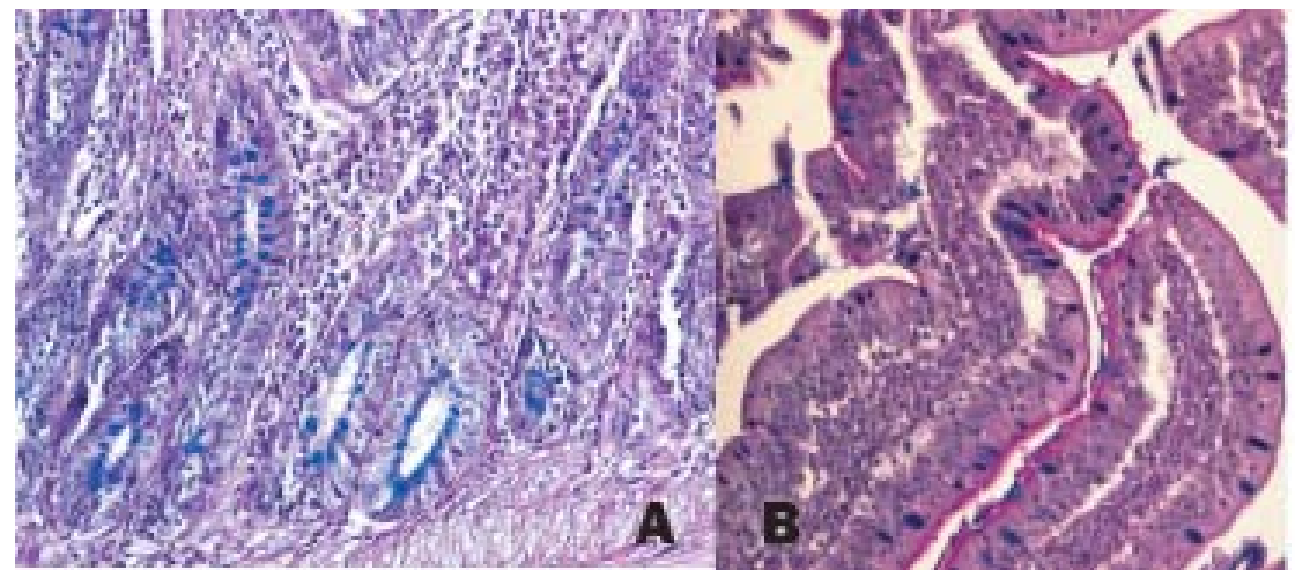

Figure 1. The effect of dietary sage on the number of cells containing acid and neutral mucins in jejunum, PAS (B). Decrease of the number of goblet cells containing acid and neutral mucins in $\mathrm{E} 3(0.05 \%$ sage $)$ compared to control, $\mathrm{AB}(\mathrm{A})$

Plasma glucose level was significantly decreased in groups of chicks fed the diet supplemented with Se and $0.05 \%$ and $0.025 \%$ sage in comparison with group fed 
diet with Se and $0.01 \%$ sage EO (glucose reference values: 11.5 - $18.0 \mathrm{mml}^{-1}$ [10]. Plasma phosphorus, magnesium and triglycerides levels and AST enzyme activity did not differ significantly between treatments (phosphorus, magnesium, triglycerides and AST reference values: $1.60-2.10 \mathrm{mmol}^{-\mathrm{l}^{-1}}, 0.75-1.3 \mathrm{mmol}^{-1} \mathrm{l}^{-1}, 0.30-0.50 \mathrm{mmol}^{-1} \mathrm{l}^{-1}$ and $1.09-1.20 \mu \mathrm{kat}^{\mathrm{l}^{-1}}$, respectively) [10].

There were no statistically significant differences in the weights of internal organs.

\section{DISCUSSION}

The gastrointestinal mucosa is constantly exposed to luminal oxidants from the ingested food. The small intestine is covered with a thinner or discontinuous mucus layer compared to the colon. In our study, the feeding diet supplemented with $0.05 \%$ sage EO significantly increased the thickness of the mucus layer in the duodenum compared with the group fed $0.01 \%$ sage EO diet (Table 2 ). This effect could be explained by initiating a higher rate of mucin production in the intestinal mucosa by sage treatment. The observed increase in the mucus layer thickness could be considered as beneficial and could indicate a dietary sage protective role. Our results are similar to the work of Tsirtsikos et al. [11] who observed a linear increase of the duodenal mucus layer thickness with increasing phytogenic feed additive dietary levels (carvacrol, anethol and limonene at concentrations of $115 \mathrm{~g} \cdot \mathrm{kg}^{-1}$ feed additive) in broiler chickens. According to Jamroz et al. [12], in groups of chickens fed with plant extract mixture (containing carvacrol, cinnamaldehyde and capsaicin) showed an increased release of large amounts of mucus and the creation of a thick layer of mucus on the wall of the jejunum.

The acidic mucins are reported to dominate in the large intestine and play a considerable role in innate immunity as they predominate in fetal and early life stages. Later, they play an important role in the local defense against pathogens. Some bacteria possess mucinspecific glycosidases and proteases which are able to degrade mucus and facilitate colonization of the epithelial surface [13]. The hydroxyl groups of sialic acid are highly substituted by acetyl esters which serve as added protection as they block against further glycosidic degradation, with reports that 2 or more acetyl groups inhibit enteric bacterial sialidases [13].

Feeding the diet supplemented with $0.05 \%$ sage EO caused an increase of numbers of cells containing both acidic and neutral mucins in the ileum. However, in the duodenum and jejunum of E3 $(0.05 \%$ sage EO) they were decreased. In the study of Forder et al. [14], a higher number of goblet cells containing acidic mucin in the ileum was observed compared to the jejunum. Similarly, in the current study, a greater amount of acidic mucins was observed in ileal goblet cells within the groups compared to the duodenum and jejunum.

The neutral mucins are reported to dominate in the gastric mucosa, however, in mammals, Sakata and Engelhardt [15] reported that neutral mucin formed the main constituents of luminal mucin in the caecum and proximal colon of mice, rats and guinea pigs. Forder et al. [14] observed an increase in goblet cells containing neutral mucin in the ileum from day 4 to day 7 posthatch in chicks compared to jejunum. Another report has demonstrated a distal increase in the density of goblet cells along the duodenal-ileal axis [16]. Similarly, in our study, the number of neutral mucins was 
much higher in the ileum within the groups in comparison with the duodenum and jejunum. On the other hand, the mean values of intestinal goblet cells containing the neutral mucin were lower in the experimental groups compared to the control.

Blood analysis showed that addition of sage extract $(0.025 \%$ and $0.05 \%)$ to the basal diet had a lowering effect on the level of glucose compared to the control. The hypoglycaemic effect of sage extrat has been reported in chickens [17], rats [18] and mice [19]. There are reports that sage increases hepatocyte sensitivity to insulin and inhibits gluconeogenesis [19].

Our results showed that feeding diet supplemented with sage EO had a reducing effect on plasma calcium levels. This is consistent with our previous finding on chicks fed a diet supplemented with graded levels of borneol (constituent of many herbal essential oils including sage), which has demonstrated a reducing effect of borneol on plasma calcium levels [20]. The effects of some herbs (sage, rosemary and thyme) and their constituent EOs and monoterpenes on bone resorption were tested in ovariectomized rats [21]. Bone resorption was inhibited by the addition of $1 \mathrm{~g}$ of powdered leaves of each herb, and the EOs extracted from sage and rosemary also inhibited resorption. Pure components from the EOs were also studied and a mixture of the four major monoterpenes which occur in sage oil (thujone, eucalyptol, camphor and borneol in proportion similar to that found in the natural oil) and were shown to inhibit bone resorption in a similar manner to the unmodified sage extract. Experiments were also carried out in vitro on osteoclasts and it was found that borneol, thymol and camphor all inhibited bone resorption at a concentration of $1.0 \mathrm{mmol} . \mathrm{l}^{-1}$. It is thought that these monoterpenes act directly on osteoclasts, not via the stimulation of calciotropic hormones, and the mode of action is thought to be via inhibition of the mevalonate pathway and prenylation of small G- proteins such as Ras, Rho and Rac [21]. 3- carene, bicyclic monoterpene in the essential oil extracted from pine trees, was shown to effect osteoblastic differenciation of mouse osteoblastic MC3T3-E1 subclone 4 cells [22]. At low concentrations of 3- carene was shown to stimulate significantly the activity and expression of alkaline phosphatase, an early phase marker of osteoblastic differentiation on differentiation day 9. On day 15, it dramatically promoted the induction of calcium in a dose - dependent manner. Although these studies report apparently contradictory data, they should not be considered to be mutually exclusive, since bone metabolism is a complex multifactorial process and it is known that stimuli can give rise to anabolic or catabolic effects depending on dosage, timing, and site of application [23]. In addition, calcium level also depends on albumin level and $\mathrm{pH}$. It is known that a minor drop of calcium exists because of a decrease in albumin level. Suprisingly, there were no differences between groups in plasma phosphorus levels. In addition to the role of the intestinal mucus layer as a defensive barrier, there is evidence suggesting that mucin has a major effect on the absorption of cations. Metal ions traverse the mucosally adherent mucus layer with an efficiency of $\mathrm{M}^{+}>\mathrm{M}^{2+}>\mathrm{M}^{3+}$ before transport by membrane proteins into the enterocytes. Thus $\mathrm{Ca}^{2+}$ binds directly to anions of globet cell mucin before uptake by the enterocytes [24]. We might suggest that sage essential oils should have a benefitial effect on bone mineralization.

Our previous experiments showed that feeding a diet supplemented with graded levels 
(0; $0.1 ; 0.05$ and $0.025 \%$ ) of essential oil from rosemary leaves (Rosmarini aetheroleum of Rosmarinus oficinalis L.) of the Spanish type (main constituents are as follows: $\alpha$-pinene $18-26 \%$, camphene $8-12 \%$, cineole $16-25 \%$, camphor $13-21 \%$, borneol $2-4.5 \%$ ) caused a significantly lower plasma calcium level in broiler chickens and the effect of rosemary essential oil on plasma calcium level tended to be dose- dependent [25].

Our results showed that feeding a diet supplemented with sage had a modulatory effect on plasma cholesterol level. There are several reports on in vivo and in vitro metabolic studies on herbal essential oils rich in small aromatic terpenoids that have been shown to reduce plasma cholesterol level by downregulating 3-hydroxy-3-methylglutaryl-CoA reductase (HMGR) expression [26].

In the present study, no significant difference in the relative weight of the internal organs was observed, which is in agreement with Hérnandez et al. [27]. Similar results were reported by Çabuk et al. [28]. They found out that dietary herbal EO mixture had no effect on body weight of broiler chicks.

In conclusion, the results of our study showed that sage EO in chickens increased the mucus layer thickness in duodenum, increased the ileal number of goblet cells containing acidic and neutral mucins, modulated plasma cholesterol, glucose and calcium levels and did not influence the relative weights of internal organs. This study contributes to the knowledge on the impact of sage on the gut, plasma indices and performance of chickens. The interactions between sage essential oil, mucin dynamics and biochemistry changes in chickens need to be further examined and better explained.

\section{ACKNOWLEDGEMENTS}

The authors wish to thank the team of Laboratório de Histologia e Anatomia Patológica, UTAD, Vila Real, PT for their help with histological stainings.

The study was supported by the Grant Agency for Science (VEGA) of the Slovak Republic No. 1/0859/11 and No. 2/0010/10.

\section{REFERENCES}

1. Smirnov A, Sklan D, Uni Z: Mucin dynamics in the chick small intestine are altered by starvation. J Nutr 2004, 134:736-742.

2. Forstner JF, Oliver MG, Sylvester FA: Production, structure and biologic relevance of gastrointestinal mucins. In: Infections of the gastrointestinal tract. Blase MJ, Smith PD, Radvin JI, Greenberg HB, Guerrant RT (editors). New York, Raven Press; 1995, 71-88.

3. Linden SK, Sutton P, Karlsson NG, Korolik V, Mc Guckin MA: Mucins in the mucosal barrier to infection. Immunology 2008, 1:183-197.

4. Trailović MS, Robertson PA, Nedeljković-Trailović J: Inhibitory effect of eugenol on rat ileal motility in vitro. Acta Vet (Beograd) 2009, 59:1223-1231.

5. Major P, Revajová V, Levkut M jr, Ševčíková Z, Spišáková V, Faixová Z, Levkutová M, Kožárová I, Goldová M, Levkut M: Intestinal mucin dynamic and leukocytic responses of chickens infected with Eimeria acervulina and fed oregano supplemented diet. Acta Vet Brno 2011, 80:147-156. 
6. Miliauskas G, Venskutonis PR, Van Beek T: Screening of radical scavenging activity of some medicinal and aromatic plant extract. Food Chem 2004, 85:231-237.

7. Thompson KL, Applegate TJ: Feed withdrawal alters small-intestinal morphology and mucus of broilers. Poult Sci 2006, 85:1535-1540.

8. Faixová Z, Piešová E, Maková Z, Levkut M jr, Pistl J, Lauková A, Faix Š, Levkut M: Effect of dietary probiotic and plant extract supplementation on mucin dynamics in the chicken intestine and on performance of chickens. Folia Vet 2012, 56(Suppl. II):15-16.

9. Lourenço L: Protocols de Rotina do Laboratório de Histologia e Anatomia Patológica. Vila Real, Portugal, UTAD; 2008, 15-16.

10. Jantosovic J: Biochemical evaluation [Biochemické vyšetrenie in Slovak]. In Diseases of poultry and exotic birds [Choroby hydiny a exotických vtákov]. Prešov, Slovak Republic: M\&M Press; 1998, 53-57.

11. Tsirtsikos P, Fegeros K, Kominakis A, Balaskas C, Mountzouris KC: Modulation of intestinal mucin composition and mucosal morphology by dietary phytogenic inclusion level in broilers. Animal 2012, 6:1049-1057.

12. Jamroz D, Wertelecki T, Houszka M, Kamel C: Influence of diet type on the inclusion of plant origin active substances on morphological and histochemical characteristics of the stomach and jejunum walls in chicken. J Anim Physiol Anim Nutr 2006, 90:255-268.

13. Corfield AP, Wagner SA, Clamp JR, Kriaris MS, Hoskins LC: Mucin degradation in the human colon: Production of sialidase, sialate O-acetylesterase, $\mathrm{N}$-acetylneruaminate lyase, arylesterase, and glycosulfatase activities by strains of fecal bacteria. Infect Immun 1992, 60:3971-1378.

14. Forder REA, Howarth GS, Tivey DR, Hughes RJ: Bacterial modulation of small intestinal goblet cells and mucin composition during early posthatch development of poultry. Poult Sci 2007, 86:2396-2403.

15. Sakata T, Engelhardt WV: Luminal mucin in the large intestine of mice, rats and guinea pigs. Cell Tissue Res 1981, 219: 629-635.

16. Uni Z, Smirnov A, Sklan D: Pre- and posthatch development of goblet cells in the broiler small intestine: Effect of delayed access to feed. Poult Sci 2003, 82:320-327.

17. Piešová E, Maková Z, Levkut M jr., Faixová Z, Pistl J, Marcin A: The effects of sage extract feed supplementation on biochemical parameters, weight of internal organs and Salmonella counts in chickens. Res Vet Sci 2012, 93:1307-1308.

18. Eidi M, Eidi A, Zamanizadeh H: Effect of Salvia officinalis L. leaves on serum glucose and insulin in healthy and streptozotocin- induced diabetic rats. J Ethnopharmacol 2005, 100:310-333.

19. Lima CF, Azvedo MF, Araujo R, Fernandes-Ferreira M, Pereira-Wilson C: Metformin-like effect of Salvia officinalis (common sage): it is useful in diabetes prevention? Brit J Nutr 2006, 96:226-233.

20. Faixová Z, Piešová E, Maková Z, Takáčová J, Čobanová K, Leng L', Faix Š: Effect of borneol on blood chemistry changes in chickens. Acta Vet (Beograd) 2009a, 59:177 - 184.

21. Mühlbauer RC, Lozano A, Palacio S, Reinli A, Felix R: Common herbs, essential oils and monoterpenes potently modulate bone metabolism. Bone 2003, 32:372-380.

22. Jeong JG, Kim YS, Min YK, Kim S: Low concentration of 3 - carene stimulates the differentiation of mouse osteoblastic MC3T3-E1 subclone 4 cells. Phytother Res 2008, 22:18-22. 
23. Putnam SE, Scutt AM, Bicknell K, Priestly CM, Williamson EM: Natural products as alternative treatments for metabolic bone disorders and for maintenance of bone health. Phytother Res 2007, 21: 99-112.

24. Powell JJ, Jugdahsingh R, Thompson RPH: The regulation of mineral absorption in the gastrointestinal tract. Proc Nutr Soc 1999, 58:147-153.

25. Faixová Z, Faix Š, Čapkovičová A: Dietary Rosmarinus officinalis extract can modulate calcium, bilirubin and lipid metabolism in broiler chickens. Folia Vet 2009b, 53:192-197.

26. Cho SY, Jun H, Lee JH, Jia Y, Kim KH, Lee SJ: Linalool reduces the expression of 3-hydroxy-3-methylglutaryl CoA reductase via sterol regulatory element binding protein-2and ubiquitin-dependent mechanisms. FEBS Letters 2011, 585:3289-3296.

27. Hérnandez F, Madrid J, Garcia V, Orengo J, Megías MD: Influence of two plant extracts on broilers performance, digestibility, and digestive organ size. Poult Sci 2004, 83:169-174.

28. Çabuk M, Bozkurt M, Alçiçek A, Akbaş Y, Küçükyılmaz K: Effect of a mixture of herbal essential oil on growth and internal organ weight of broilers from young and old breeder flocks. South Afric Anim Sci 2006, 36:135-141.

\title{
EVALUACIJA UTICAJA ESENCIJALNOG ULJA SALVIA OFFICINALIS NA BIOHEMIJSKE VREDNOSTI U PLAZMI, SLUZNICU CREVA I KVANTITET KISELIH I NEUTRALNIH MUCINA U CREVIMA PILIĆA
}

\author{
ČAPKOVIČOVÁ Adriana, MAKOVÁ Zuzana, PIEŠOVÁ Elena, ALVES Anabela, \\ FAIX Štefan, FAIXOVÁ Zita
}

Studija se odnosi na posmatranje efekata Salvia officinalis L. esencijalnih ulja na debljinu sluznice creva i kvantitet neutralnih i kiselih mucina kod pilića. Formirano je pet grupa sa po 9 jednodnevnih pilića rase Isa Brown koji su u narednih 11 nedelja hranjeni na sledeći način: kontrolna (C) grupa je dobijala osnovni obrok sa dodatkom Na selenita (Se) u koncentraciji 0,04 ppm + suncokretovo ulje (1\%); eksperimentalne grupe E1 do $\mathrm{E} 4$ : isto kao $\mathrm{C}$ grupa uz dodatak esencijalnog ulja žalfije (EO) u koncentraciji 0,01\%, 0,025; 0,05\% odnosno 0,1\%. Debljina sloja mukusa u duodenumu je značajno porasla kod pilića E3 grupe (Se i 0,05\% EO ulja) u poređenju sa E1 grupom (Se i 0,01\% EO ulja). U E3 grupi (Se i 0,05\% EO ulja) broj peharastih ćelija koje sadrže kisele i neutralne mucine je značajno bio smanjen u duodenumu i jejunumu, a povećan u ileumu u poređenju sa $\mathrm{C}$ grupom. Ishrana sa dodatkom Se i 0,01\% EO ulja žalfije (E1) izazivala je smanjenje koncentracije holesterola u plazmi u poređenju sa E3 (Se i 0,05\% EO žalfije). Dodavanje Se i 0,05\% EO žalfije (E3) kao i 0.1\% EO ulja (E4) izazvalo je smanjenje koncentracije kalcijuma u plazmi u poređenju sa E2 (Se i 0,025\% EO ulja). Koncentracije glukoze u plazmi su značajno bile smanjene u grupama koje su dobijale Se i $0,05 \%$ (E3) i 0,025\% EO (E2) ulja žalfije, u poređenju sa E1 grupom (0,01\% EO ulja). Različiti sastavi obroka po grupama nisu imali uticaja na mase unutrašnjih organa pilića u ogledu. Rezultati ukazuju da efekat EO žalfije na dinamiku adherencije sloja mukusa kao i na tip i distribuciju mucina u crevima pilića zavisi od doze EO kao i od segmenta creva uz istovremeno postojanje potrebe da se obave dalja ispitivanja u cilju detaljnog objašnjenja ovog uticaja. 